\title{
Interovarian relationship in the secretion of progesterone during the luteal phase of the capuchin monkey (Cebus apella)
}

\author{
C. A. Nagle, N. Paul, I. Mazzoni, S. Quiroga, M. Torres, A. F. Mendizabal \\ and Z. Farinati
}

Centro de Investigaciones en Reproducción Humana y Experimental. Centro de Educación Médica e Investigaciones Clinicas (CEMIC), Galván 4102, 1431 Buenos Aires, Argentina

\begin{abstract}
Summary. In basal conditions, progesterone concentrations were similar in the ovarian veins of the ovary $+\mathrm{CL}(3211 \pm 526 \mathrm{ng} / \mathrm{ml})$ and the ovary $-\mathrm{CL}(3165 \pm 554 \mathrm{ng} / \mathrm{ml})$, but after blocking the blood flow between the ovary + CL and the uterus, the progesterone values in the vein draining the ovary $-\mathrm{CL}$ decreased to $1218 \pm 394 \mathrm{ng} / \mathrm{ml}$ $(P<0.01)$. When $\left[{ }^{3} \mathrm{H}\right]$ progesterone was injected in the ovary $+\mathrm{CL}$, the radioactivity appeared earlier and more concentrated in the vein draining the ovary - CL ( $30 \mathrm{sec}$, $0.53 \%$ of injected dose) than in the femoral vein ( $150 \mathrm{sec}, 0.08 \%$ of injected dose). Removal of the ovary + CL was followed by a brief maintenance of peripheral progesterone within luteal-phase levels. The in-vitro progesterone production by a suspension of cells isolated from the corpus luteum was $47.5 \pm 12.8 \mathrm{ng} / \mathrm{ml} / 2 \mathrm{~h}$, whereas luteal-like cells isolated from the ovary $-\mathrm{CL}$ secreted $14.3 \pm 6.0 \mathrm{ng} / \mathrm{ml} / 2 \mathrm{~h}(P<0.01)$ into the medium. We therefore suggest that the symmetrical and high secretion rate of progesterone by the ovaries of the capuchin monkey indicates a between-ovary communication system, and that the luteal-like tissue of the ovary - CL can produce relatively large amounts of progesterone.
\end{abstract}

Keywords: capuchin monkey; luteal phase; ovarian vein; progesterone

\section{Introduction}

The ovarian cycle of New World monkeys is characterized by the secretion of high concentrations of steroids, in particular progestagens (Preslock et al., 1973; Wolf et al., 1977; Bonney et al., 1979). In the capuchin monkey the circulating concentrations of progesterone are 2-12 times higher than those observed in Old World primates and human beings (Nagle et al., 1979).

We have published data on the origin of circulating progesterone in the female capuchin which suggested that both ovaries should contribute with similar levels of steroid hormones (Nagle \& Denari, 1983) in spite of the ovulation being unilateral (Nagle et al., 1980). Nevertheless, it was observed that, during the luteal phase, the progesterone secreted by the non-ovulating ovary decreased after the removal of the ovary bearing the corpus luteum (Nagle \& Denari, 1983). These results led us to postulate that, in the capuchin, there may be a between-ovary communicating system via the uterine circulation which equilibrates the progesterone concentrations in the 2 ovaries.

Even though little is known about the uterine and ovarian vasculature in the capuchin monkey, there is anatomical and functional evidence compatible with the existence of such transuterine venoarterial pathway connecting both ovaries for rhesus monkeys (Riesen et al., 1970; Ginther et al., 1974) and for women (Jacobs, 1969; Mendizabal et al., 1985). However, it is also 
possible that the high concentration of progesterone found in the vein draining the ovary without the corpus luteum was due to the production of progesterone by the large amounts of luteal-like tissue present in this ovary (Nagle \& Denari, 1983).

The present study was designed to investigate the origin of the progesterone secreted by the ovary not containing the corpus luteum.

\section{Materials and Methods}

Sexually mature female capuchin monkeys (Cebus apella) were used. The care, general maintenance and reproductive characteristics of these animals have been described previously (Nagle \& Denari, 1982).

The 15 monkeys were individually caged and had been carefully followed for $2-3$ months before study, with daily vaginal smears to detect menstruation and to verify a cycle regularity of 18-22 days. Blood samples ( $1 \mathrm{ml})$ were obtained on a daily basis by femoral venepuncture beginning on Day I of the cycle (first day of menstruation), until the animals were laparotomized on Day 13-15 during the luteal phase. Only monkeys having a normal luteal phase with plasma progesterone values $>40 \mathrm{ng} / \mathrm{ml}$ were subjected to laparotomy.

The monkeys were anaesthetized with ketamine hydrochloride (Ketalar: $20 \mathrm{mg} / \mathrm{kg}$ : Parke Davis \& Co., Buenos Aires, Argentina). The side containing the fresh corpus luteum was identified (ovary $+\mathrm{CL}$ ) and one of two protocols was followed.

Protocol I. Two experiments were designed to investigate communication between the ovaries. In Exp. 1, involving 6 females, a sample of systemic blood was taken from the femoral vein; thereafter, $1 \mathrm{ml}$ blood was taken from each ovarian vein using heparinized syringes fitted with 25 -gauge needles. A haemostat was then placed on the broad ligament to prevent blood flow between the ovary $+C L$ and the uterus, and a second sample was obtained from the ovarian vein of the ovary without the corpus luteum (ovary $-\mathrm{CL}$ ). Subsequently, the clamp was removed and peripheral blood was sampled every $24 \mathrm{~h}$ until next onset of menses. In Exp. 2 with 2 females, $1.5 \mu \mathrm{Ci}$ [1,2,6,7,21- $\left.{ }^{3} \mathrm{H}\right]$ progesterone (sp. act. 163.5 Ci/mmol: New England Nuclear Corp., Boston, MA, USA) dissolved in $5 \mu$ l saline $(0.154 \mathrm{M}-\mathrm{NaCl})$ were injected into the ovary $+\mathrm{CL}$, proximal to the insertion of the utero-ovarian ligament. Blood samples from the femoral and ovarian vein, opposite the ovulatory side, were collected at time 0 and at 15-20-sec intervals after the injection of labelled progesterone. A single drop of blood was spread on 5-mm discs of filter paper (S and S grade 903, Schleicher and Schuell Inc., Keene, NH, USA), penetrating it from one side to the other. The radioactivity of each disc was eluted in toluene-based scintillation fluid and counted to a counting error of less than $1 \%$ in a Beckman model LS 7000 liquid scintillator. The c.p.m. measured were corrected for quenching using an external standard and recorded as d.p.m./disc.

In the capuchin monkey the term ovarian vein refers, as it does in the rhesus monkey (Ginther et al., 1974), to the vessels which drain the ovaries and enter the inferior vena cava on the right side and the renal vein on the left.

Protocol II. This study was designed to examine the ability of the ovary $-\mathrm{CL}$ to produce progesterone. In 4 animals, the vessels of both ovaries were clamped simultaneously and the ovaries were removed. In 3 other monkeys, only the vessels of the ovary -CL were clamped and this ovary was removed. In both groups of animals, blood samples were withdrawn from the femoral vein at $0,1,3,6,12,18$ and $24 \mathrm{~h}$ after surgery. Thereafter, blood was sampled every $24 \mathrm{~h}$ until the next onset of menses. The plasma disappearance time $\left(t_{t}\right)$ was estimated from the semilogarithmic plot of the decay of plasma progesterone following either bilateral or unilateral ovariectomy.

The ovaries from bilaterally ovariectomized monkeys were utilized within $15 \mathrm{~min}$ after surgery for short-term in-vitro analysis of progesterone production, as described by Stouffer et al. (1976). Fragments of the fresh corpora lutea weighing $80-120 \mathrm{mg}$ (wet tissue) and pieces of luteal-like tissue removed from the ovary - CL under a binocular dissection microscope $(\times 6)$, weighing $70-90 \mathrm{mg}$ wet tissue/ovary, were cut into slices and dispersed in TC-199 nutrient medium with $25 \mathrm{~mm}$-Hepes buffer, $2 \%$ bovine serum albumin (BSA) and $2 \%$ collagenase (Sigma Chemicals Co., St Louis, MO, USA). The slices were incubated separately at $37^{\circ} \mathrm{C}$ in a shaking water bath under an atmosphere of $95 \% \mathrm{O}_{2}$ and $5 \% \mathrm{CO}_{2}$ at an initial concentration of approximately $50 \mathrm{mg}$ wet tissue $/ \mathrm{ml}$. After three medium renewals the dispersed cells were collected by low-speed centrifugation $(150 \mathrm{~g})$, washed twice and resuspended in fresh TC 199-Hepes medium containing $2 \%$ BSA. The cells were counted with a haemocytometer. The number of cells recovered ranged between $1.2 \times 10^{6}$ and $3 \times 10^{6}$. Contamination with other than the luteal-type cells was less than $5 \%$. Cell viability, assessed by means of trypan blue exclusion (Tennant, 1964), was $80-90 \%$. Incubations were carried out in duplicate for $2 \mathrm{~h}$ at a final concentration of $2.5 \times 10^{5}$ viable cells $/ \mathrm{ml}$, in $2 \mathrm{ml}$ TC 199-Hepes-BSA medium at $37^{\circ} \mathrm{C}$ under $95 \% \mathrm{O}_{2}-5 \% \mathrm{CO}_{2}$, with constant shaking. At specified time intervals, $25 \mu \mathrm{l}$ medium were removed from each sample and frozen at $-15^{\circ} \mathrm{C}$ until progesterone assay.

Progesterone radioimmunoassay. Blood was centrifuged within $30 \mathrm{~min}$ after collection and the plasma was separated and frozen at $-15^{\circ} \mathrm{C}$ until assayed. The progesterone content of peripheral and ovarian plasma samples and culture media was determined by radioimmunoassay as described previously (Nagle et al., 1979). Ovarian plasma samples were diluted 10 times with human male serum. For the extraction procedure, $400 \mu \mathrm{l}$ assay buffer and $100 \mu \mathrm{l}$ human male serum were added to $25 \mu \mathrm{l}$ samples of plasma and culture media samples and the steroid was extracted with $5 \mathrm{ml}$ petroleum ether. The extracts were brought to dryness in air, reconstituted in 2-5 $\mathrm{ml}$ buffer and assayed in 
duplicate using a specific antiserum against progesterone-3-(O-carboxymethyl)-oxime-BSA. The antiserum was used at a 1:16800 dilution. Other progestagens (20a-hydroxy-pregn-4-en-3-one; 17,20-dihydroxypregn-4-en-3-one and $17 \alpha$-hydroxyprogesterone) cross-reacted $<10 \%$ with this antiserum. Non-progestagenic steroids also had $<10 \%$ cross-reaction with the antiserum. The intra-assay coefficient of variation was between 3 and $10 \%$. Values for inter-assay coefficient of variation based on repeated measurements in different assay runs of pools of monkey plasma with high and low progesterone concentrations were between 8 and $16 \%$. Recovery values after extraction were consistently around $92 \%$. Sensitivity of the assay was $14.5 \mathrm{pg} /$ tube. The progesterone concentration in $100 \mu \mathrm{l}$ samples of human male serum (blanks) was $16 \cdot 6 \pm 1 \cdot 1 \mathrm{pg}(n=11)$.

Statistical analysis. Data were analysed statistically by Student's $t$ test.

\section{Results}

\section{Between-ovary connections}

The progesterone values obtained in peripheral and ovarian venous blood samples collected before and after preventing blood flow between the ovulatory ovary and the uterus are shown in Table 1. In basal conditions, the progesterone concentration in the femoral vein varied between 49 and $124 \mathrm{ng} / \mathrm{ml}$, whereas the steroid concentrations in both ovarian veins were symmetrical and between 22 and 39 times higher than the simultaneous peripheral value. There was, in general, parallelism between concentrations of progesterone in ovarian and peripheral plasma. In two monkeys (Nos 76 and 152) the steroid values in the vein of the ovary -CL were slightly higher than those in the vein of the ovary +CL. Mean values were not statistically different. The blood flow blockade from the ovulatory side throughout the uterus resulted in a $62 \%$ decrease in the progesterone concentration in the ovarian vein on the contralateral side $(P<0.01)$, although the concentrations were still approximately 13 -fold higher than in peripheral venous blood. Transient prevention of blood flow between ovaries did not modify the subsequent peripheral concentration of progesterone (curve not shown); the luteal phase was not disrupted by this procedure and all monkeys of this group menstruated at the expected time according to their menstrual histories, 5-7 days after surgery.

Table 1. Progesterone concentrations in peripheral and ovarian venous plasma in the luteal phase of capuchin monkeys

\begin{tabular}{lcccc}
\hline & \multicolumn{4}{c}{ Plasma progesterone $(\mathrm{ng} / \mathrm{ml})$} \\
\cline { 3 - 5 } & & \multicolumn{3}{c}{ Ovarian vein } \\
\cline { 3 - 5 } & & \multicolumn{3}{c}{ Side opposite CL } \\
\cline { 3 - 5 } Monkey & $\begin{array}{c}\text { Peripheral } \\
\text { vein }\end{array}$ & Side of & Before & $\begin{array}{c}\text { After } \\
\text { blocking }\end{array}$ \\
blocking \\
\hline 54 & 63 & 1563 & 1416 & 962 \\
76 & 121 & 4407 & 4652 & 3042 \\
2 & 49 & 1900 & 1200 & 560 \\
152 & 124 & 4032 & 4707 & 722 \\
132 & 115 & 4500 & 4378 & 1520 \\
131 & 76 & 2864 & 2640 & 505 \\
Mean \pm s.e. & $91 \pm 13$ & $3211 \pm 526$ & $3165 \pm 664^{\mathrm{a}}$ & $1218 \pm 394^{\mathrm{b}}$ \\
\hline
\end{tabular}

a vs $\mathrm{b}, P<0.01$.

The distribution of radioactivity after injecting $\left[{ }^{3} \mathrm{H}\right]$ progesterone in the ovary $+\mathrm{CL}$ is shown in Fig. 1. Simultaneous sampling of blood from the ovarian and femoral veins of the opposite side revealed that, as early as $30 \mathrm{sec}$ after the injection, the radioactivity appeared in the ovarian vein 
draining the ovary $-\mathrm{CL}$, reaching a peak, representing $0.53 \%$ of the injected dose, $180 \mathrm{sec}$ later. Meanwhile, in the femoral vein, the radioactivity appeared later; it was detected $150 \mathrm{sec}$ after the isotope injection and peak values representing $0.08 \%$ of the injected dose were detected at 220 sec.

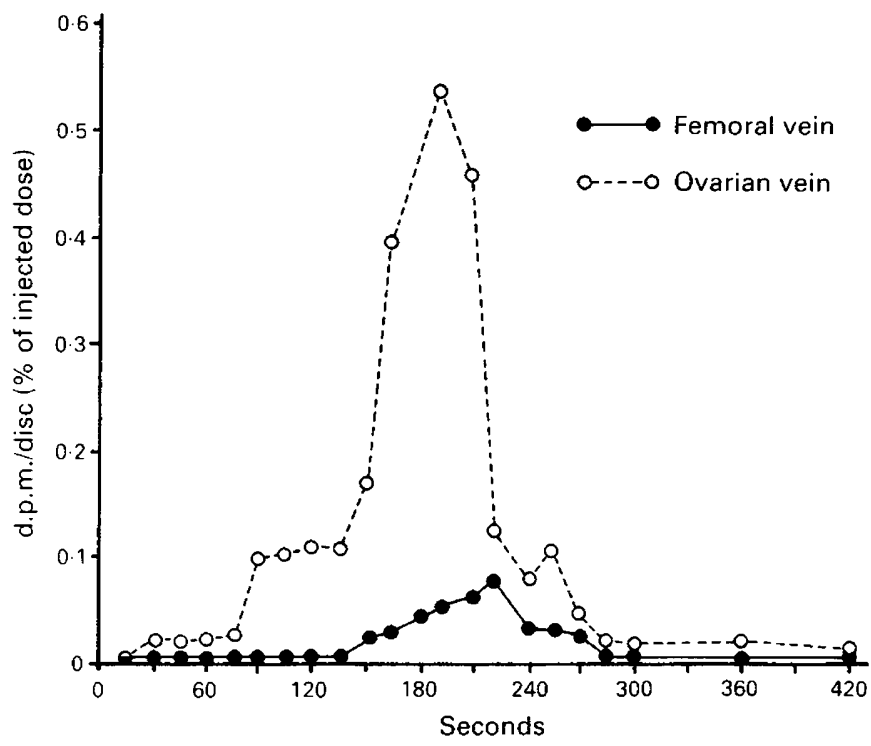

Fig. 1. Pattern of radioactivity in blood drawn from the femoral vein and ovarian vein of the non-ovulatory side after a single injection of tritiated progesterone into the ovary bearing the corpus luteum. Each point represents the mean of 2 animals. The values in the femoral vein between 15 and $130 \mathrm{sec}$ and between 270 and $420 \mathrm{sec}$ were indistinguishable from the blank.

\section{Progesterone kinetics}

As shown in Fig. 2 bilateral ovariectomy was followed within $6 \mathrm{~h}$ by a $50 \%$ fall $\left(t_{\frac{1}{2}} 1.4 \mathrm{~h}\right)$ in serum progesterone values $(P<0.01)$. After $24 \mathrm{~h}$, the steroid had decreased further and at $48 \mathrm{~h}$ values were $10 \%$ of initial concentrations, coinciding with the onset of menses. After ablation of the ovary $+\mathrm{CL}$ the peripheral progesterone concentrations declined more slowly. There was no significant effect within $6 \mathrm{~h}$ after surgery. By $12 \mathrm{~h}$, the levels of this steroid decreased by about $30 \%$ $(P<0.05)$, reaching values representing $50 \%$ of basal $(P<0.01)$ at $24 \mathrm{~h}\left(t_{\frac{1}{2}} 20 \mathrm{~h}\right)$. At $48 \mathrm{~h}$ after surgery, progesterone had declined to values of bilaterally ovariectomized monkeys and menses ensued.

\section{In-vitro study}

Under similar incubation conditions, the accumulation of progesterone in the culture medium of luteal cells from the ovary +CL and luteal-like cells from the ovary -CL was linear (Fig. 3), the ovary + CL cells showing a greater increase. After $2 \mathrm{~h}$ of incubation, the cells from the ovary $-\mathrm{CL}$ released to the culture medium amounts of progesterone representing $25 \%$ of that by luteal cells of the ovary + CL. 


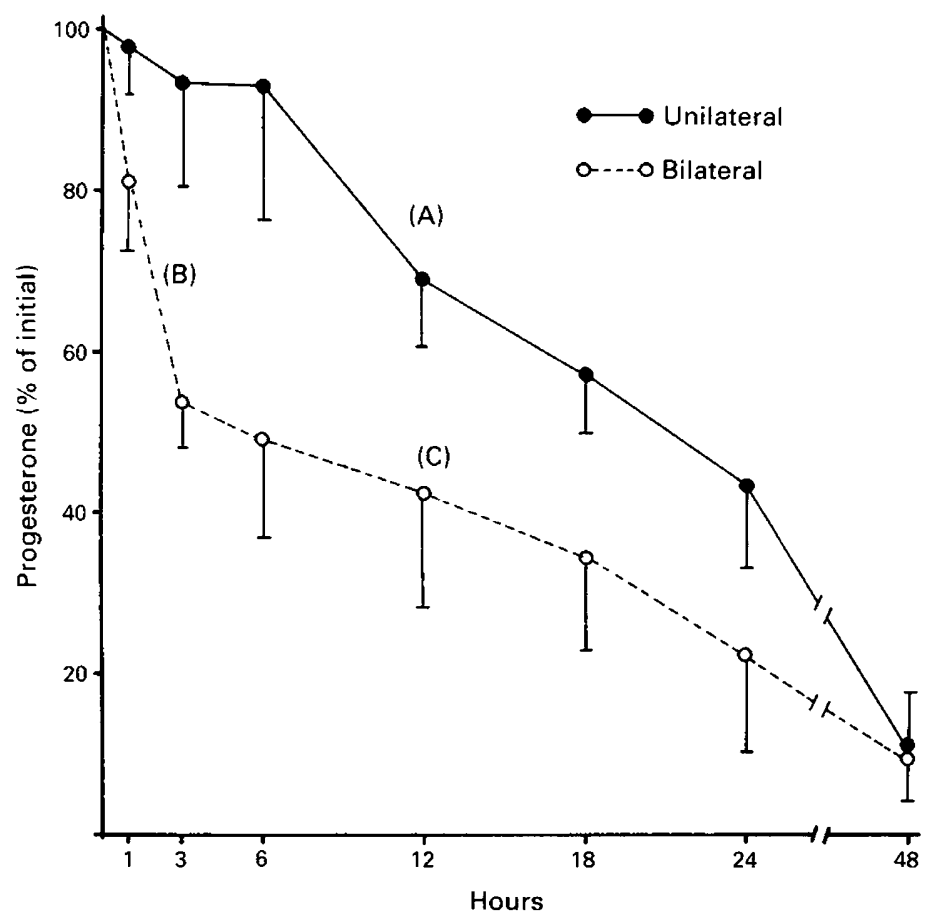

Fig. 2. Rate of progesterone disappearance from peripheral blood after bilateral ovariectomy $(\mathrm{N}=4)$ or removal of the ovary bearing the corpus luteum $(\mathrm{N}=3$ ). The results (mean \pm s.e.m.) are expressed as percentage values with respect to the concentration of the hormone at zero time $(100 \%)$. When plotted on a semilog scale (not shown) the apparent $t_{1}$ of component $\mathrm{A}$ $(0-48 \mathrm{~h})$ was $20 \mathrm{~h}$; of component B $(0-3 \mathrm{~h})$ was $1.4 \mathrm{~h}$ and, for $\mathrm{C}(3-48 \mathrm{~h})$, the $t_{\frac{1}{2}}$ was $18 \mathrm{~h}$.

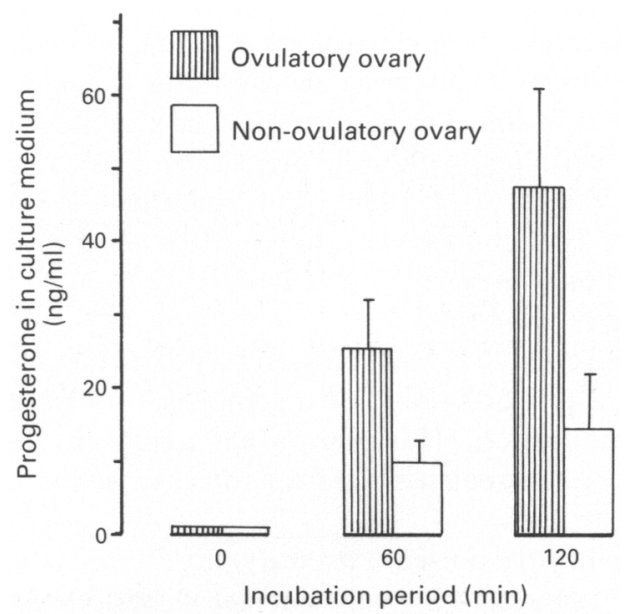

Fig. 3. Progesterone secretion by suspensions of luteal cells obtained from the corpus luteum $(\mathrm{N}=3)$ and luteal-like cells isolated from luteal-like tissue of the non-ovulating ovary $(\mathrm{N}=3)$. The cells were incubated in duplicate at a concentration of $2.5 \times 10^{5}$ cells $/ \mathrm{ml}$. Values are mean \pm s.e.m. for 6 determinations. 


\section{Discussion}

The results of this study indicate that the symmetrical concentrations of progesterone in the veins draining the ovaries of capuchin monkeys are the consequence of a transuterine circulation, whereby progesterone produced by the corpus luteum reaches the contralateral ovarian vein. After prevention of the blood flow between the ovary $+\mathrm{CL}$ and the uterus, the progesterone concentrations in the vein draining the ovary $-\mathrm{CL}$ dropped markedly. Additional evidence was obtained when radioactive progesterone was injected into the ovary $+\mathrm{CL}$ and the radioactivity was recovered earlier and more concentrated from the vein draining the ovary $-\mathrm{CL}$ than from the femoral vein. Although in this experiment it was not proved that the radioactivity recovered was progesterone, it does demonstrate that the mixture of blood between the ovaries may normally occur.

A transuterine circulation communicating both ovaries has been proposed for the rhesus monkey (Riesen et al., 1970; Ginther et al., 1974), and for women (Jacobs, 1969; Mendizabal et al., 1985). However, unlike the capuchin, both the rhesus and the woman manifest asymmetry in the ovarian venous progesterone concentrations during the luteal phase (Lloyd et al., 1971; Resko et al., 1975). A further difference is that in capuchin monkeys the progesterone concentration in the vein draining the ovary - CL remained several times higher than in peripheral blood after blocking blood flow from the ovary $+\mathrm{CL}$, whereas in rhesus monkeys and women the steroid concentration in the vein of the ovary -CL decreases to near peripheral values after blocking (Riesen et al., 1970; Mendizabal et al., 1985).

Our results in the capuchin monkey could be accounted for by the ability of the ovary $-\mathrm{CL}$ to produce progesterone. This assumption is supported by the differences observed in the rate of disappearance of peripheral progesterone after removing both ovaries or only the ovary + CL. Although both procedures terminated the cycle in progress and the onset of menses was equally advanced, unilaterally ovariectomized monkeys showed a slower rate of disappearance of peripheral progesterone, with a brief maintenance of the steroid within luteal levels. The reason why the ability of the ovary - CL to secrete progesterone appeared to become exhausted a few hours after the removal of the ovary bearing the CL is uncertain. This observation would appear to indicate that trophic substances from the ovary $+C L$ were affecting the ovary $-C L$ to stimulate the extra-luteal production of progesterone. In the rhesus monkey, the responsiveness of the luteallike tissue to hCG decreased as the time elapsed from the removal of the corpus luteum increased (diZerega \& Hodgen, 1982).

The ability of the luteal-like cells to produce progesterone was conclusively demonstrated in our in-vitro experiments. Under similar incubation conditions, the capacity of these cells for producing progesterone was $25 \%$ of that of luteal cells from the ovary $+\mathrm{CL}$. However, it is likely that the mass of the luteal-like cells distributed within the ovaries can be as much as or even exceed that of luteal cells from a single CL (Nagle et al., 1980; Nagle \& Denari, 1983) and although it is difficult to assess what their relative contributions are likely to be in vivo, it does appear that, in the capuchin monkey, the luteal and luteal-like tissue work in concert to provide the extremely high concentrations of circulating progesterone.

Chrousos et al. (1982) suggested that the high secretory rates and elevated plasma progesterone concentrations in New World primates could be a compensatory response to a decreased uterine progesterone receptor concentration. However, a reduction in the number of endometrial progesterone receptors was not associated with an increase in the circulating progesterone in women (Keller et al., 1979).

Nagle \& Denari (1983) have reported extremely high unmetabolized progesterone in the urine of capuchin monkeys, suggesting a particular rate of peripheral metabolism and clearance of this steroid. Undoubtedly, the physiological basis for and significance of the high circulating concentrations of progesterone in Cebus and other New World monkeys are more complex and the characteristics of the transport and metabolism will have to be investigated to explain the apparent progesterone resistance in these primates. 
We believe that a between-ovary communication involving a transuterine venoarterial pathway could provide the anatomical basis for a direct regulation of the life-span of the corpus luteum through the interaction of locally produced luteotrophic (i.e. chorionic gonadotrophin) and luteolytic (i.e. prostaglandin F-2 $\alpha$ ) agents (Rothchild, 1981; Hearn \& Webley, 1987). Likewise, the presence of vascular channels which permit blood from one ovary to flow to the contralateral one would constitute the way through which progesterone (Goodman \& Hodgen, 1982) and other factors (diZerega et al., 1982) might act as local determinants of the pre-eminence of one ovary, resulting in single ovulations, despite the exposure of both ovaries to similar amounts of pituitary gonadotrophins.

We thank Dr Enrique Adamoli for assistance in surgery and $\mathrm{Mr}$ Armando Gette and $\mathrm{Mr}$ Guillermo Gette for expert technical assistance.

C.A.N. is a member of the National Research Council (CONICET), Argentina.

\section{References}

Bonney, R.C., Dixson, A.F. \& Fleming, D. (1979) Cyclic changes in the circulating and urinary levels of ovarian steroids in the adult female owl monkey (Aotus trivirgatus). J. Reprod. Fert. 56, 271-280.

Chrousos, G.P., Renquist D., Bandon, D., Barnard, D., Fowler, D., Loriaux, D.L. \& Lipsett, M.B. (1982) The squirrel monkey: Receptor mediated end-organ resistence to progesterone? J. clin. Endocr. Metab. 55, 364-368.

diZerega, G.S. \& Hodgen, G.D. (1982) The inter-ovarian progesterone gradient: a spatial and temporal regulator of folliculogenesis in the primate ovarian cycle. $J$. clin. Endocr. Metab. 54, 495-499.

diZerega, G.S., Goebelsmann, U. \& Nakamura, R.M. (1982) Identification of protein(s) secreted by the preovulatory ovary which suppresses the follicle response to gonadotrophins. J. clin. Endocr. Metab. 54, 1091-1096.

Ginther, O.J., Dierschke, D.J., Walsh, S.W. \& Del Campo, C.H. (1974) Anatomy of arteries and veins of uterus and ovaries in rhesus monkeys. Biol. Reprod. 11, 205-219.

Goodman, A.L. \& Hodgen, G.D. (1982) Antifollicular action of progesterone despite hypersecretion of FSH in monkeys. Am. J. Physiol. 243, (Endocrinology and Metabolism 6); E387-E397.

Hearn, J.P. \& Webley, G.E. (1987) Regulation of the corpus luteum of early pregnancy in the marmoset monkey: local interactions of luteotrophic and luteolytic hormones in vivo and their effects on the secretion of progesterone. J. Endocr. 114, 231-239.

Jacobs, J.B. (1969) Selective gonadal venography. Radiology 92, 885-888.

Keller, O.W., Wiest, W.G., Askin, F.B., Johnson, L.W. \& Strikler, R.C. (1979) Pseudo corpus luteum insufficiency: a local defect of progesterone action on endometrial estroma. J. clin. Endocr. Metab. 48, 127-132.

Lloyd, Ch.W., Lobotsky, J., Baird, D.T., McCraken J.A., Weisz, J., Pupkin, M., Zañartu, J. \& Puga, J. (1971) Concentration of unconjugated estrogens, androgens and gestagens in ovarian and peripheral venous plasma of women: the normal menstrual cycle. J. clin. Endocr. Metab. 32, 155-166.
Mendizabal, A.F., Nagle, C.A., Adamoli, E., Torres, M., Mazzoni, I., Quiroga, S. \& Farinati Z. (1985) Between-ovary interactions during woman menstrual cycle. In Volume in honor of D. B. Kaskarelis, pp. 269-274 Ed. D. Arabantinos. Helenic Society for Studies in Reproduction, Atenas.

Nagle, C.A. \& Denari, J.H. (1982) The reproductive biology of capuchin monkeys. Int. Zoo Ybk 22, $143-150$.

Nagle, C.A. \& Denari, J.H. (1983) The Cebus Monkey (Cebus apella). In Reproduction in New World Primates, pp. 41-67. Ed. J. P. Hearn. MTP Press, Lancaster.

Nagle, C.A., Denari, J.H., Quiroga, S., Riarte, A., Merlo, A., Germino, I., Gomez Argaña, F. \& Rosner, J.M. (1979) The plasma pattern of ovarian steroids during the menstrual cycle in the capuchin monkey (Cebus apella). Biol. Reprod. 21, 979-983.

Nagle, C.A., Riarte, A., Quiroga S., Moreno Azorero, R., Carril, M., Denari, J.H. \& Rosner, J.M. (1980) Temporal relationship between follicular development, ovulation and ovarian hormonal profile in the Capuchin monkey (Cebus apella). Biol. Reprod. 29, 629-635.

Preslock, J.P., Hampton, S.H. \& Hampton, J.K., Jr (1973) Cyclic variations of serum progestines and immunoreactive estrogens in marmosets. Endocrinology 92, 1096-1101.

Resko, J.A., Köering, M.J., Goy, R.W. \& Phoenix, C.H. (1975) Preovulatory progestins: observations on their source in rhesus monkeys. J. clin. Endocr. Metab. 41, 120-125.

Riesen, J.W., Köering, M.J., Meyer, R.K. \& Wolf, R.C. (1970) Origin of ovarian venous progesterone in the rhesus monkey. Endocrinology 86, 1212-1214.

Rothchild, I. (1981) The regulation of mammalian corpus luteum. Recent Prog. Horm. Res. 37, $183-298$.

Stouffer, R.L., Nixon, W.E., Gulya's, B.J., Johnson, D.K. \& Hodgen, G.D. (1976) In vitro evaluation of corpus luteum function of cycling and pregnant rhesus monkeys: progesterone production by dispersed luteal cells. Steroids 27, 543-551. 
Tennant, J.R. (1964) Evaluation of the trypan blue techniques for determination of cell viability. Transplantation 2, 685-696.
Wolf, R.C., O'Connor, R.F. \& Robinson, J.A. (1977) Cyclic changes in plasma progestines and estrogens in squirrel monkey. Biol. Reprod. 17, 228-231.

Received 23 March 1988 